\title{
2
}

\section{The Company of St Teresa of Jesus at New Norcia, 1904-10}

On 6 June 1908 Sister Maria Harispe, a member of the Company of St Teresa of Jesus, wrote to Father Henry Altimira, secretary to New Norcia's second abbot Fulgentius Torres. After nine months at New Norcia and approaching her third year in temporary vows as a lay sister with the Teresian community of missionary teachers, the 26-year-old wrote to Henry Altimira as someone she trusted and who knew the background of her situation. She wrote in her own hand, and in Spanish, the language of Paraguay, her home country. Faced with a disintegrating community and an imminent departure from New Norcia, Maria asked to remain at the West Australian mission. Her letter was not intended to be more than a personal statement, but it held the seed of the new style of monastic missionary presence that would emerge from the ashes of the Teresian community to become the Benedictine Missionary Sisters of New Norcia. Maria's urgent hopes for a future at New Norcia named priorities and pitfalls that had haunted the Teresian enterprise and would remain powerful themes in the lives of all the Spanish women who were involved at the mission through the next seven decades. This chapter sets the experience of these first Spanish missionary sisters in the context of their congregation's foundation in Barcelona and then focuses on the Teresian years at New Norcia, between 1904 and 1910, to tease out the themes of religious commitment, of ethnic and racial identity, of gender and institutional hierarchies, of class and educational opportunity that were formative of later patterns at St Joseph's. 
We begin with Maria's letter because it encapsulates the crisis that marks the end of the Teresian story at New Norcia and because it points towards new and different structures. She probably wrote her letter upstairs in the south-west tower of St Gertrude's College. The fine new building bore the Teresian crest, but only the southern tower, accessible by a back stairway, was serving as a convent for the Teresian sisters, as the newly arrived Sisters of St Joseph of the Sacred Heart, Irish-Australian members of Mary MacKillop's group, had the front door keys and were launching the first year of St Gertrude's school downstairs. ${ }^{1}$ Maria's letter, in response to this and much else, asked Father Altimira to help her persuade the abbot to keep her on as a worker and to send her to the new mission he was planning in the Kimberley. Her request came after careful and unromantic discernment of her decision through the wintery rains of June and flowed from faith that God had inspired her overriding commitment to missionary work with the Aboriginal people:

After having commended to the Lord the matter which you already know, and especially during this month, and after having asked Him with all the sincerity of my heart for the grace to know His most holy will about putting my desires into operation, I find myself determined to follow this way of abnegation and sacrifice for His love. Since as far as I can understand, although no angel from heaven came down to reveal it to me, I think it will be God's will when He gives me these desires. Therefore I ask you sincerely to intercede for me with Reverend Father Abbot that he may deign to admit me for the mission of the north, which one who although [a] miserable and cowardly soldier is offering herself as a volunteer. ${ }^{2}$

1 On the early days of St Gertrude's, see Marie Therese Foale, The Josephites Go West: The Sisters of St Joseph in Western Australia 1887-1920 (Fremantle, WA: University of Notre Dame Press, 1995), 68-75; Anne Carter and Elizabeth Murphy, A Rich Harvest-St Gertrude's College (South Perth: Sisters of St Joseph of the Sacred Heart, 2006), 6-9, 20-26. On the move to the south-west tower of the 'New College', 'Chronicle of the Benedictine Community of New Norcia' (hereafter Chronicle), 17 August 1907, 14 March 1908, New Norcia Archives (NNA). See also Katharine Massam, "“To Know How to Be All for All”: The Company of St Teresa of Jesus at New Norcia 1904-1910', New Norcia Studies 15 (2007): 44-52.

2 Maria Harispe to Henry Altimira, 6 June 1908, in the 'Canonical Visitation to the Community of Teresians of St Gertrude's New Norcia, October 1907', trans. David Barry, OSB, NNA 01717 (hereafter Visitation), 82. 
She signed herself with her full name in religion, Sister Maria Teresa de Jesus Harispe, and went on to detail her motivation for volunteering for the new mission. She documented her sense of call to the work and her particular promise to 'sacrifice' her own family connections in favour of a missionary life. She stressed her commitment to the Aboriginal people, who, in the Spanish of her day, were matter-of-factly 'blacks' and 'savages', 'despised by the majority of people' but loved by Maria:

First, because since I heard that a house was going to be founded in Australia for the natives I always had the desire that they might send me. Secondly, so to live separated from the world and above all from my relatives which sacrifice I offered the Lord in a special way on the day of my religious profession. Thirdly, out of the compassionate love which I have towards the blacks for being so despised by the majority of people. Fourth, because I would desire to sacrifice my life for the savages and I would consider myself very happy if I could finish my life amongst them. ${ }^{3}$

She hesitated to tell the abbot's secretary of three requirements she saw as essential to her offer, but with a frank admission of her fear she would be laughed at she explained her hopes that she could continue to be identified as a religious sister, even as she sought to align herself with the Aboriginal people for the rest of her life:

Concerning the conditions I will speak to you when I see you since I think that they are as it were some three conditions and indispensable which if I put them to you I have no doubt that you will laugh. Shall I put them to you? Yes. Firstly, that I may always be able to use the religious habit even though it be of sackcloth. Secondly, that they may regard me as a native as far as my clothing and other necessities. Thirdly, a plot of land when I die and a requiescat in pace. ${ }^{4}$

Maria's letter pivots between stages in her life: she will not renew her vows with the Teresians, and she will transfer to New Norcia's structures. It also serves to introduce the four powerful themes that marked the identity of the Teresian sisters and also threaded through the experience of later missionary women at New Norcia. They were Spanish, or if not born in Spain they were Spanish speakers from Spanish colonies, who had left their own empire to work in an outpost of Great Britain. From Mediterranean 
and South American countries, they were also olive-skinned, ready to identify with the Aboriginal people and in a dubious position in the racial hierarchies that preoccupied White Australia. ${ }^{5}$ They were missionaries for Catholicism who spoke a language of faith and salvation that they hoped to offer to the people they encountered. The prevailing Protestant assumptions in Australia alarmed and dismayed them. They were sisters, members of a community of religious women, and in this they belonged to a category that might be named even more powerfully as 'not monks'. On each of these counts, and framing them, they were outsiders, falling between categories and frequently separated from direct decision making. An account of the congregation's foundation in nineteenth-century Barcelona frames the hope expressed by their Teresian superiors in Spain: that at New Norcia, the community would 'know how to be all for all'. 6

\section{The Company of St Teresa of Jesus}

A 36-year-old priest of the Diocese of Barcelona, Enrique Ossó y Cervelló, established the Company of St Teresa of Jesus in 1876. A teacher of mathematics at the diocesan seminary, Osso had a devotion to the sixteenth-century Carmelite foundress, Teresa of Avila, and a conviction that Christian education was the only thing that could transform society and draw it into Christ. The organisation of missionary teachers that he drew together, initially eight young women, was pledged to missionary outreach, drawing inspiration from Teresa of Avila. The present-day Teresians, now with communities in 23 countries, remember that Osso told the founders they were committed to:

A work of zeal to make you other Teresas in so far as possible, so that you might be foremost in promoting the honour of Jesus. Praying, teaching, and sacrifice is the honour of the Society.?

As Osso wrote textbooks for the Teresian schools, the new group expanded rapidly from Barcelona to South America, in particular to Uruguay, Paraguay and Mexico. Young women from those countries

5 On the 'non-white' status of Spain, see Marilyn Lake and Henry Reynolds, Drawing the Global Colour Line: White Men's Countries and the Question of Racial Equality (Melbourne: Melbourne University Press, 2008), 24, 101, 105; J. Lyng, Non-Britishers in Australia: Influence on Population and Progress (Melbourne: Macmillan and Melbourne University Press, 1927), vi-vii, 4-5.

6 Saturnina Jassa to Fulgentius Torres, 30 April 1908, Visitation, 41.

7 Company of St Teresa of Jesus, www.teresians.org; accessed 25 April 2007. 
joined them, including Maria Harispe, a French citizen from Paraguay, and Consuelo Batiz from Mexico. These two recruits, along with Teresa Roca from Barcelona, would become particularly important for the New Norcia story.

Osso also set up a teacher-training institute in the motherhouse in Barcelona. This Colegio Teresiano, now a prestigious secondary school, was one of the first buildings designed and built by Antoni Gaudí in 1889 and was full of the intriguing detail that would mark his style. Osso was uneasy about its high style and quirkiness; in response Gaudí was reported to have told his friend the founder: 'To each his own Fr Henry. You say Mass so that I may build houses'. ${ }^{8}$ That division of labour settled, he ensured a building that reflected the Teresians' unusual commitment to education, both in their investment in professional training for the women who would teach and in what they would offer to children, especially girls, in mission countries. The founder was fond of remarking that ' $[t]$ he world has always been what women made it'," and education was a key to shaping their influence.

So, it was not so surprising that Fulgentius Torres, new abbot of the Benedictine mission at New Norcia, would think of the Teresians when he was seeking a community of women religious who could work with the Aboriginal women and girls at New Norcia. In fact, after ensuring the return to New Norcia of the body of Rosendo Salvado, New Norcias founding abbot, from St Paul's Outside the Walls in Rome where he had died in December 1900, Torres announced that his highest priority would be to find women to take charge of what the Western Australian Government called 'St Joseph's Native School and Orphanage'. Archbishop Casanas of Barcelona recommended the Teresians. They honoured the Black Madonna, patroness of Barcelona, and they regarded her shrine, downhill from the monastery of Montserrat, as a place of particular inspiration. ${ }^{10}$ Torres himself, as a monk of Montserrat, had met both the founder and the first sisters in 1885 and had kept track of the community over some

8 'Colegio de las Teresianas', Gaudi Barcelona Club, www.gaudiclub.com/esp/e_vida/teresian2. html; accessed 25 April 2007.

9 Enrique de Ossó y Cervelló, Escritos (Barcelona: Ediciones STJ, 1976), 207, cited by Pope John Paul II in his homily at the canonisation, 16 June 1993, w2.vatican.va/content/john-paul-ii/es/homilies/ 1993/documents/hf_jp-ii_hom_19930616_canonizzazione-madrid.html; accessed 15 April 2018. See also Alejandro Fernandez Pombo, Saturnina Jassá de la Compañia de Santa Teresa de Jesús (Barcelona: Ediciones STJ, 1991), 135.

10 'Quienes Somos', Compañia de Santa Teresa de Jesús, www.stjteresianas.org/quienes-somos/ lugares-significativos/; accessed 12 October 2018. 
25 years since. ${ }^{11}$ In Spain again on behalf of the mission, Abbot Torres made contact with the superior general Mother Teresa Blanche, and the monastery's community diary or Chronicle records that a contract was approved on 8 June $1903 .^{12}$

At three o'clock in the afternoon of 25 August 1904, a party of nine Teresian sisters arrived in buggies at New Norcia. Two of the monks had met them from the steamer Stuttgart at Fremantle, the abbot and the prior went to greet them on the road while the bells rang out, and 'the whole community' went to the mission church to chant the Te Deum in thanksgiving. ${ }^{13}$ The sisters, travelling in black, cape-like habits and plain black veils, would remember they 'were given a warm welcome by the girls who had adorned themselves with bush flowers in their hats'. ${ }^{14}$ Sure enough, in the photograph to commemorate the new community at St Joseph's the same wide-brimmed almost ostentatious hats marked the young women from the children in straw boaters and the new arrivals in their tight veils. Two members of the Teresians' provincial council, Mother Teresa Pla and Mother Josefa Beltran, had come to learn about their new foundation firsthand; the seven other travellers, Montserrat Fito, Consuelo Batiz, Felipa Sanjuan, Maria Teresa Vilar, Leonor Bargallo, Teresa Roca and Carmen Mayordom, would stay 'to care for the education of the girls'. ${ }^{15}$

On 11 December 1904, responsibility for St Joseph's passed into the hands of the Teresians. Only two of the community moved to the orphanage, a whitewashed wooden cottage dating from 1861, but all 'helped during the day'. They expected to move out of the two-storeyed guest house in front of the church and into their own new convent and school when construction was complete. Building had begun as they had left Europe, and the monks, perhaps unaware of the high standards set by Gaudís

11 Torres to unnamed cardinal, 19 December 1907, Visitation, 60; [Torres, Fulgentius], The Torres Diaries, 1901-1914: Diaries of Dom Fulgentius (Anthony) Torres y Mayans, O.S.B., Abbot Nullius of New Norcia, Bishop Titular of Dorylaeum, Administrator Apostolic of the Kimberley Vicariate in North Western Australia, trans. Eugene Perez, ed. Rosemary Pratt and John Millington (Perth: Artlook Books, 1987), 12.

12 Chronicle, 8 June 1903.

13 Chronicle, 25 August 1904.

14 'Origen de la Congrecacion de las Hermanas Benedictinas Misioneras de New Norcia, Western Australia' unpublished typescript from the notebooks of Sister Felicitas Pampliega c. 1921-c. 1967, transcribed and edited by Sister Teresa González, Madrid c. 1980, Archives of the Benedictine Missionary Sisters of Tutzing (ABTM) (hereafter Notebooks, Madrid), 1.

15 Chronicle, 22 August 1904. 
motherhouse, expected the facilities 'to be magnificent'. ${ }^{16}$ Recording the transfer, the Chronicle interlaced the three strands of Spanish identity, missionary vocation, and the call for women, as 'sisters-not-monks', suited to work with women:

Brother Friolán Miró today began to follow all the acts of the community; till today for the last 30 years he has had charge of the education of the Aboriginal girls. He educated, cared for and watched over them day and night, doing as much as a mother could have done for them. The great inconvenience is obvious to anyone who thinks about it, which is the reason why the Abbot has not rested until he could bring out the Teresian Sisters of recent formation of D. Enrique de Osso priest; they have taken charge of the aforementioned girls, caring for them better than the virtuous and patient $\mathrm{Br}$ Miró and without the danger that resulted. He only goes to the college to sleep, the aim being to act as interpreter for the Sisters should anything happen since they do not yet understand the girls' language. ${ }^{17}$

The account is expansive by the standard of the Chronicle's brief entries, marking an important occasion. The Teresians brought a religious identity as sisters to the work that local women, including Judith Butler as schoolmistress and Eliza Willaway as one of the Aboriginal matrons, had been doing alongside Brother Miró. ${ }^{18}$ The Teresians took up the missionary tasks of care and education, and they faced these as Spanish women unable to speak 'the girls' language'. (This intriguing phrase might suggest something other than English, but probably reflects the Chronicle's own distance from English rather than another lingua franca. Certainly by 1908, it was English that the Teresians were struggling to understand as they interacted with the St Joseph's girls.)

16 Chronicle, 27 July 1904, 24 September 1904.

17 'Notes on the Teresian Sisters in New Norcia', trans. Fr David Barry, NNA 01717, original emphasis; Chronicle, 11 December 1904.

18 Katharine Massam, 'Cloistering the Mission: Abbot Torres and Changes at New Norcia 19011910', Australasian Catholic Record 89 (2012): 13-25. 


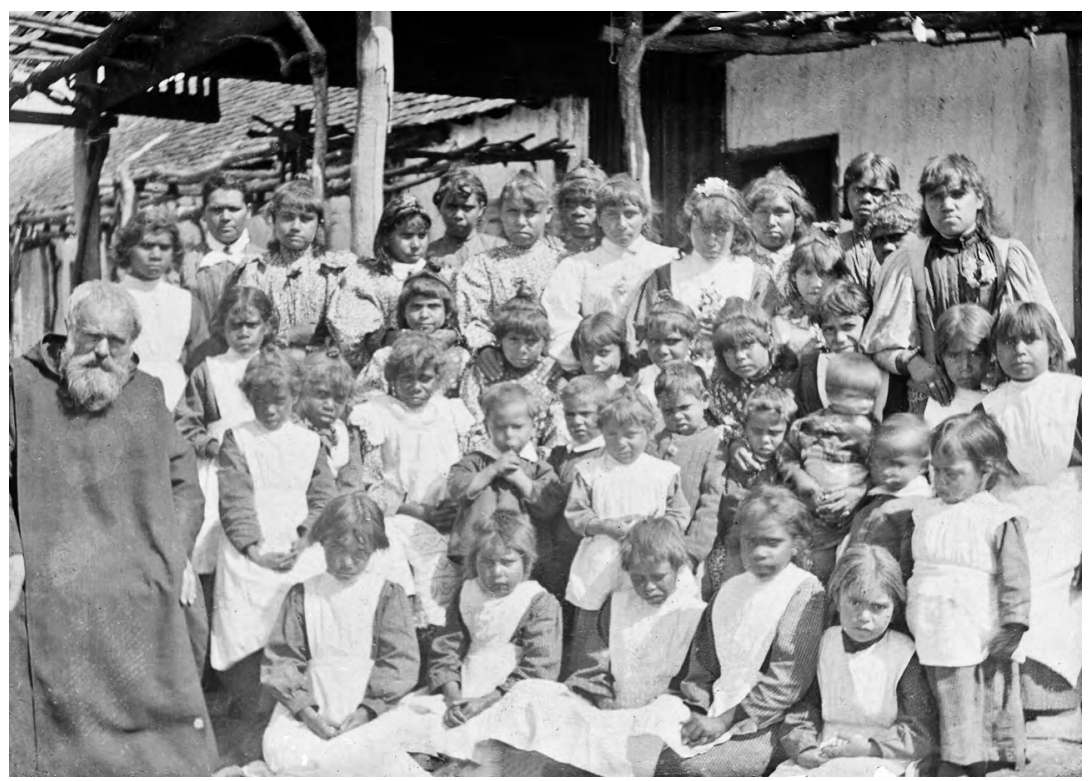

Figure 2.1: Brother Friolán Miró and the residents of St Joseph's before 1904.

Source: NNA 73609P.

The abbot had high hopes for the missionary women, but these were unrefined times at New Norcia. A monk wanting a bath still used the 'ram's trough' in a paddock, and the lay brothers did the laundry in the river. ${ }^{19}$ Practical demands came first. Perhaps it is the matter-offact announcement in the Chronicle two days after the sisters took over at St Joseph's that reveals most about the expectations of their work. The diarist noted: 'The Teresian Sisters have made a habit for Fr Alcalde. They are also mending the old habits of the community'. ${ }^{20}$ Three months later the diarist celebrated the expansion of the domestic work at St Joseph's, announcing that 'for the first time the girls of the College have washed the clothes of the community'. ${ }^{21}$ Whether this was the kind of work the Teresians expected their school to be doing, the Chronicle does not say, but later events suggest it was not. Teacher education, missionary vocation and refined taste all paled beside the expectation that the women would do the washing and mend the clothes.

19 Chronicle, 31 January 1905, 13 March 1905.

20 Chronicle, 13 December 1904.

21 Chronicle, 13 March 1905. 


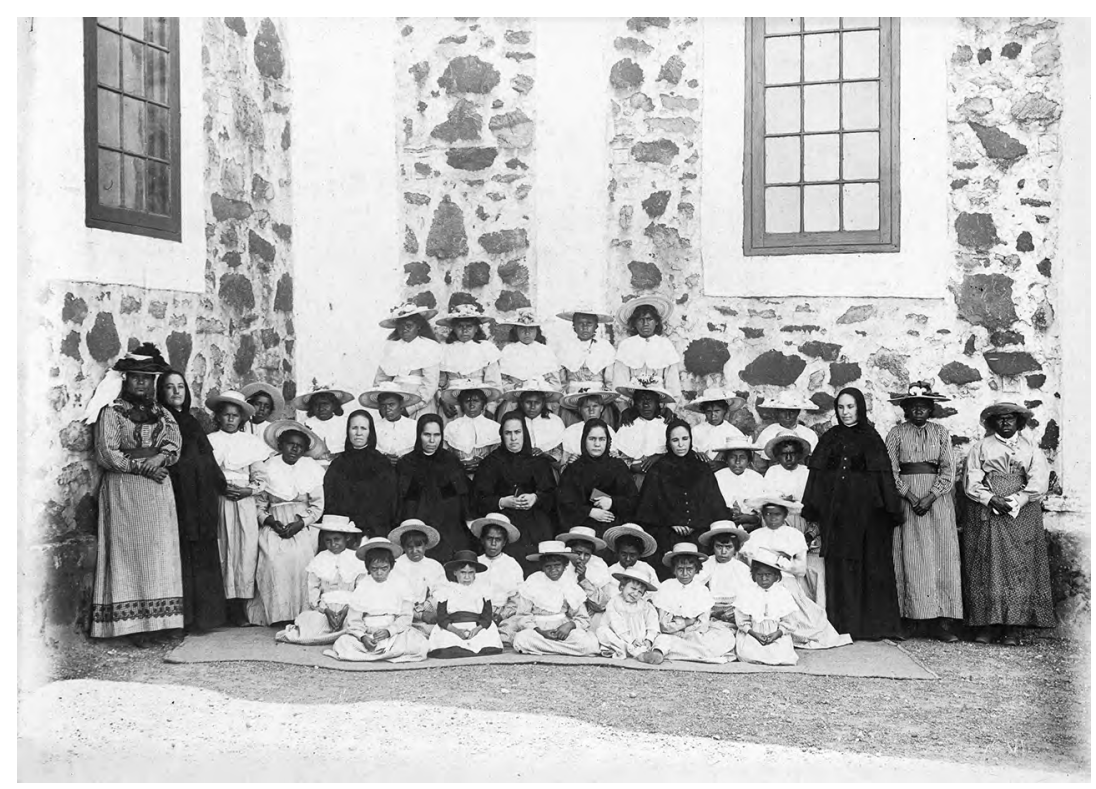

Figure 2.2: The first Teresian community at New Norcia with residents of St Joseph's, 1904.

Source: NNA 73743P.

There are no photographs of the community at work, but we do have an image of the group at St Joseph's taken soon after the sisters arrived, posed in careful rows. As discussion of the photographic collection at New Norcia as a whole has shown, ${ }^{22}$ the image marking the occasion of the Teresians' arrival reveals but also conceals. The image is one of half a dozen or so photographs of the sisters in their time at New Norcia. They are always pictured with the St Joseph's girls. Unlike later communities of sisters at New Norcia, there are no group photos of the Teresian sisters by themselves or in informal settings. In a context where the Western Australian Parliament was moving towards the 1905 legislation on Aboriginal people, the so-called Protection legislation that actually introduced greater segregation and separation from families, the anxiety about St Joseph's that comes through in the monastery Chronicle was not unique.

The arrival photograph was one answer to that anxiety, perhaps. As with any historical evidence, however, we cannot be absolutely sure of what we are seeing. Some of the women in this picture meet our gaze, and some

22 For papers from the 2014 symposium 'Ways of Telling: Images of Salvado and the New Norcia Mission'; see New Norcia Studies 22 (2015). 
avoid it. The children scowl, squint or face the camera calmly. Teresa Roca, the lay sister seated on the right, seems lost in thought as one girl rests a hand on her shoulder and another chooses not to. No one smiles, but the Aboriginal matron on the far left has a white cockatoo on her shoulder, tucked in close under the brim of her hat. A subversive gesture or a signal of the daily reality? We can speculate but we cannot know what the women are thinking or how they are feeling.

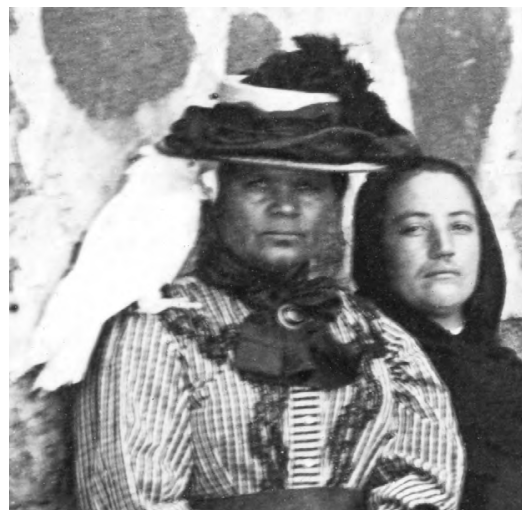

Figure 2.3: Detail of Teresian arrival: Aboriginal matron with a cockatoo on her shoulder.

Source: NNA 73743P.

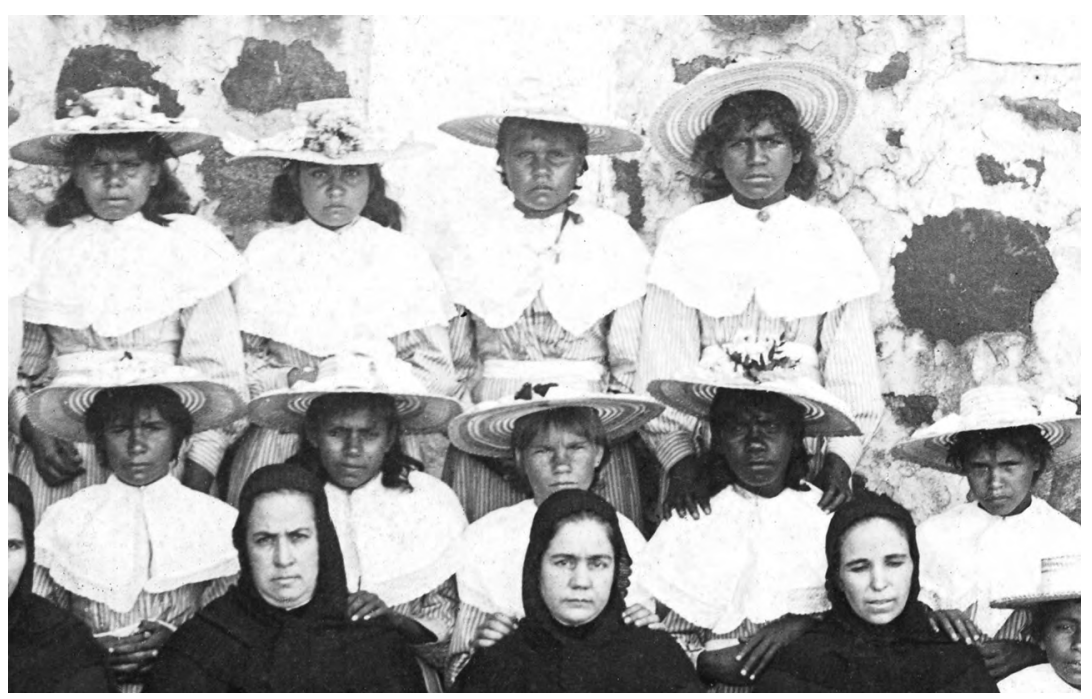

Figure 2.4: Detail of Teresian arrival: Teresa Roca and other sisters with St Joseph's girls behind.

Source: NNA 73743P. 
Our focus for the moment is on the Teresian sisters. Like missionary women in many other contexts, their history is written in the 'white ink' of discounted experience. ${ }^{23}$ The milky white ink is often lost between the lines, or visible only through accounts of other people, such as photographs for the Catholic press and administrative records that trace their interaction with the church and the state. Occasionally, we get a sense of personality and the echo of a personal voice in those records, and even more so in the letters they wrote to the abbot and other officials, usually written in times of crisis-as Maria Harispe's letter was written to Henry Altimira, for example. More often, we only have glimpses to piece together and passing remarks in other accounts to rely on.

Take, for example, the account of Maria Harispe's own arrival at New Norcia. She came not with the foundation party but three years later, in 1907. Our main source for this information is a shipboard diary kept by a young monk travelling in the abbot's party of nine, probably one Miguel Angel Estremera. As the German liner Seydlitz set out from Genoa in July 1907 he kept note of the distance travelled and the miles that remained until Fremantle; he recorded heat, thirst, seasickness, sightings of whales and of rainbows. Like many diary writers, he kept an eye lightly on his reader, apologising for smudges and 'the badly chosen selection of events of our journey'. ${ }^{24} \mathrm{He}$ took his readers into his confidence a little. We know he respected the abbot, who threw a medal of St Benedict overboard, 'so that the sea may calm itself' 25 and they could celebrate Sunday Mass. He noted the success of a concert and the abbot's work as accompanist ('Well done Father', applauded Miguel, 'A Protestant public! All for the greater glory of God!'26), as he noted the concert seating-children apart, gentlemen at one table, religious persons (including himself) at another, and then, with the ladies, there were also 'the Sisters'. These sisters, and all of the party except the abbot, were seasick as they crossed the equator and for days afterwards. But the weather calmed and they recovered, and after five weeks at sea they stood on deck together to watch the Australian coast appear. At the last, he names Abbot Torres and the five other Benedictine men, 'plus' he says, 'four Sisters of the Congregation of St Teresa of Jesus and a Spanish married couple'. ${ }^{27}$

23 Gerda Lerner, The Majority Finds Its Past (Oxford: Oxford University Press, 1981), 145-59.

24 'Viaje de Génova a Nueva-Norsia (Australia)', trans. Carlos Lopez, NNA 00033 (hereafter Viaje), Sunday 18 August 1907.

25 Viaje, 3 August 1907.

26 Viaje, 5 August 1907.

27 Viaje, 18 August 1907. 
These he does not name, and we have no shipboard diary for them. We know that they were travelling with the abbot and his party, and at New Norcia they knew to expect the woodworker and sculptor Juan Casellas and his wife Catalina, as well as the four sisters whose names they did not know. ${ }^{28}$ As the diary draws to a conclusion Miguel explains the party's shared purpose in terms that had been popular in Spanish missionary literature since the sixteenth century. They had shared this journey, he says, 'for the Greater Glory of God, to profit our own souls and the Mission, whose purpose is to procure salvation for the Blacks who dwell there'. ${ }^{29}$ The journey was nearly over, and the party would be testing their assumptions against the reality of the new place. Let us follow the account for just a little longer.

It was Sunday, so there was only one train that day from the port at Fremantle to the city, Perth. Waiting to catch it, the party attracted attention. Whether because of their dark skin, their monastic clothes, or their Spanish talk, Miguel did not know or say, but he recorded the jolt, in national terms:

I was surprised that these English, famed for their indifference and education, were perplexed to see us; such was their astonishment that they stopped and laughed as though we were strange beasts. ${ }^{30}$

Even at its port, Western Australia was homogenous enough to know whom to label strange. The diary rushes on, but all of a sudden everything is compared to what he had known at home: the train was inferior to Spanish railcars; the views from the window were not pretty, all billboards; the hotel lunch had no wine, although they asked, only sherry with dessert. And then Perth itself. It was larger in size than Barcelona, but not as beautiful: it was all trams, asphalt, more timber than stone; in fact, he says, 'I would not give ten cents for it'. ${ }^{31}$ He was a little more relaxed about the large park with walkways, the river-wider than the Ebro at Tortosa-and the Catholic cathedral, 'raised by the Brothers from the Mission', ${ }^{32}$ where in the evening a good congregation gathered for devotions with a sermon in English and sung litanies. But we can hear the writer's shock and a reassertion of Spanish assumptions.

\footnotetext{
28 Chronicle, 19 August 1907.

29 Viaje, 18 August 1907.

30 Viaje, 18 August 1907.

31 Viaje, 18 August 1907.

32 Viaje, 18 August 1907. As Frances Stibi shows, this was a widespread misunderstanding about the role of the Benedictines in Perth. See 'Cathedral Construction: Building the Cathedral of the Immaculate Conception’, New Norcia Studies 14 (2006), 1-13.
} 
The next day, the party set off at eight in the morning for Mogumber by train, a journey of four-and-a-half hours, and the prose expands again. The writer appreciated what he saw: eucalyptus forests and green fields, stations that 'find themselves all alone'; ${ }^{33}$ and then a further journey from Mogumber in 'carts'; ${ }^{34}$ until suddenly, 'a great surprise to the traveller to see such a beautiful town spring out of the forest'. ${ }^{35}$ 'They were welcomed with New Norciass ritual of everybody turning out on the road. Miguel's travel diary was approaching its conclusion and he records it this way:

At half past three we alighted and were made welcome by the gathered community, the boys school and the girls school and other inhabitants, their children blacker than coal. Under an arch with the English and Spanish flags and many banners, we crossed towards the church to sing a Te Deum in thanks. Afterwards we went to eat and to install ourselves. ${ }^{36}$

But you have not arrived until you know where you are, so the next day there was a full tour, and Miguel celebrated what he saw, again in national terms. It surpassed Europe; it surpassed 'the [local] English': ${ }^{37}$

[W] visited the various parts of the Monastery, the girls' school close to being finished; would that Europe had such a thing, it is no wonder that the English seem astonished [as] ... there is nothing like it in all Australia. ${ }^{38}$

The diary keeper is becoming less of a stranger at every step. As they walk around the town he catalogues the signs of progress-the mill, the saw, the noodle-making machine, the engine configured as at home, the workshops, harvesters and brick kiln. 'In other words', he sums up, 'thanks be to God and to the Abbots that have governed here, we lack for nothing. ${ }^{39}$ In a burst of generous acknowledgment he adds: 'Thanks also to the freedom given by the English government'. ${ }^{40}$ Then he signs off, with the initials for the Latin declaration, 'May God be glorified in all things': UIOGD.

33 Viaje, 18 August 1907.

34 Chronicle, 19 August 1907, records the urgent borrowing of two coaches from the neighbouring

Clune and Lanigan families to add to the monastery's trap, so they could meet the party in style.

35 Chronicle, 19 August 1907.

36 Chronicle, 19 August 1907.

37 Chronicle, 19 August 1907.

38 Chronicle, 19 August 1907.

39 Chronicle, 19 August 1907.

40 Chronicle, 19 August 1907. 
Meanwhile, at the southern end of town, the newly arrived superior of the Teresian community, Sister Crisanta Lopez, was sitting down at the table with her community - three other new arrivals and five who had been at the mission for three years. As she sat down, Crisanta, also thanking God, made an impact on her sisters with a very different view of the journey Miguel has described. Apparently she exclaimed: 'Thanks be to God we can eat free of the presence of the monks! We are full of monks, up to the top of the head'. ${ }^{41}$ Sister Carmen, one of the established group, was credited by the others as advising Crisanta that 'the Abbot was a kind man'. At the table the old community of five (Carmen Mayordom, Maria Teresa Vilar, Felipa Sanjuan, Leonor Bargallo and Teresa Roca) went on to tell the newcomers (Crisanta Lopez, Luz Castañada, Dolores Sol de Vila and Maria Harispe) 'all that could be known' about Abbot Torres, including prudent advice that 'she should be somewhat careful with him'. ${ }^{42}$

Perhaps they included some stories of the former superior, Montserrat Fito, and her deputy in charge of the school, Consuelo de la Cruz Batiz, who had been recalled to Spain just five weeks earlier on 11 July 1907. Perhaps, but the subject was raw. The sudden order from Barcelona recalling both sisters had fallen 'like a bomb' on the whole town. ${ }^{43}$ The Teresians were 'not able to get out of the amazement that the decision of the superiors ... has caused them'. The 15 Aboriginal residents at St Joseph's withdrew their participation from public prayer and 'spent two days in which, in the Church, they could not respond to the Priest leading the Rosary', perhaps through sorrow, or in protest, or maybe both. ${ }^{44}$ Two girls left St Joseph's and hid under the arches of the 'New College' with a wild plan to meet up with one of the workers. When they were discovered, the sisters initially accepted 'their sadness at the departure of Sr Consuelo' as a plausible excuse. ${ }^{45}$ The monks recorded that Montserrat's departure was 'what the Aborigines and Europeans of these environs want'. ${ }^{46}$ She had opposed Consuelo. The loss of Consuelo herself was a great blow. The Chronicle is clear that the mission owed her 'so much gratitude, more than to all the other Sisters combined'. ${ }^{47}$ She was one 'who has earned the respect of the Aborigines in the village and in particular the girls in the College (of which she had been in charge since the Sisters started to

41 Teresa Roca, 30 October 1907, Visitation, 10.

42 Teresa Roca, 30 October 1907, Visitation, 10.

43 Chronicle, 6 July 1907.

44 Chronicle, 11 July 1907, 18 July 1907. On the numbers at St Joseph's over time, see Appendix 1.

45 Chronicle, 22 July 1907.

46 Chronicle, 5 July 1907.

47 Chronicle, 16 July 1907. 
run it), and not excluding the Aboriginal people who admired her and venerated her very much'. ${ }^{48}$ There had been a rift between the two local leaders, and Barcelona attempted to resolve it by recalling them both and sending a new superior.

The local community was reeling. The monastery's Chronicle observed that ' $[\mathrm{t}]$ he jealousy of the superior has taken from the Mission the Sister who has worked the hardest for the Mission itself'. ${ }^{49}$ As Abbot Torres eventually explained to the Teresian superior general, Sister Consuelo had been at the core of his hopes for the new school, simply 'the Sister who in the judgement of those close to her and of strangers could have been put in charge of the college both of white girls and of native girls without delay'. ${ }^{50}$ But now, arriving home to the new situation and after a voyage where 'neither the new superior nor any of the Sisters ... asked one question about the Sisters here or about the people and things in the mission', Abbot Torres could not bring himself to make the customary courtesy call to the sisters who had been waiting for his return. ${ }^{51}$ As the new superior, and the one sent to replace Consuelo in the school, Crisanta Lopez walked into a context where all of New Norcia's communities were alarmed and confused. She would have been well-advised to go gently.

Whatever the sisters said around the table at that first meal, we know it was not a good beginning for Crisanta. The fragments of their lunchtime conversation survive because within three months Abbot Torres and his secretary Henry Altimira were conducting a canonical visitation into the governance of the Teresian community, recording accusations and counteraccusations among the sisters. Within six months Mary MacKillop's Sisters of St Joseph (Josephites) arrived to teach in English at the girls' school. And in another six months the abbot and the Teresian superior in Barcelona were exchanging telegrams and letters, each threatening the other with withdrawing or banishing the sisters and leaving the other party to explain to the Congregation for the Propagation of the Faith in Rome. In late November 1907 Crisanta and Luz returned to Spain, and Sister Felipa Sanjuan, who had made her final profession at New Norcia in August only the year before, became the new stop-gap superior. ${ }^{52}$

50 Fulgentius Torres to Saturnina Jassa, Superior General of the Company of St Teresa of Jesus, 3 May 1908, Visitation, 43.

51 Chronicle, 21 and 24 August 1907.

52 Record, 11 August 1906, 17; Chronicle, 23 November 1907. 
In April 1908 the newly elected superior in Barcelona, Saturnina Jassa, and her councillor, Teresa Pla, wanted to renew the commitment to New Norcia. But the abbot's secretary advised them to stop trying to solve the situation: 'I understand the sign INRI has been well and truly fixed on this cross', Altimira wrote, 'it only remains to bear the burden of disappointment'. ${ }^{53}$ On 10 October 1908 a further four Teresians were recalled. All three who remained-Maria Harispe, Leonor Bargallo and Teresa Roca-petitioned the abbot to be permitted to stay and work at New Norcia or in the new mission in the north. Marias hope could be accommodated with the support of the monks because her temporary vows as a Teresian expired in July 1909 but Leonor and Teresa were bound to obedience in permanent vows. They were finally recalled to Spain, and in February 1910 Maria Harispe was alone in charge of St Joseph's. How did it come to this?

At the centre of what we know is the report of the canonical visitation and the letters and telegrams collected with it. These valuable documents were preserved at New Norcia when other Teresian material that might have given more background was burnt during the Spanish Civil War. Through the visitation records, the three categories of identity that Maria's letter itself introduced—ethnicity, spirituality and gender-emerge as important touchstones. When we put the quasi-judicial record of 1907 alongside the day-to-day Chronicle kept by the Benedictine monks to record their own life in the town, we have glimpses of the impact of a fourth category: race. What did it mean for the Teresians to be Spanish, missionaries, and members of a vowed community? How did these categories of identity intersect with the markers of 'Whiteness' that implicitly shaped the dynamics of the mission town?

\section{Spanish identity}

The importance of Spanish identity had preoccupied New Norcia's monks as they framed the first invitation to women to share the work of the mission. At a 'Community Council' held on 6 October 1902, a mere four days after the abbatial election that confirmed Fulgentius Torres as Salvado's successor, and only four days before Torres left for Europe, the monks had five items of business to determine. They agreed unanimously on buildings first and last: to complete the addition of the third floor to

53 Henry Altimira to Teresa Pla, 8 June 1908, Visitation, 48. 
the existing monastery and to plan for a new structure on the hill near the post office. The proposal 'afterwards to construct a house for the girls; to bring nuns to educate them ${ }^{34}$ drew so much discussion 'about what nuns would be suitable and of what nationality's5 that there was, however, no formal vote. The Chronicle considered the options in terms of location, with support divided between the Sisters of the Good Samaritan, founded in 1857 by John Bede Polding, the Benedictine archbishop of Sydney 'in that capital', others who favoured 'those in Perth or Fremantle', and still others 'who wanted them from Spain'. ${ }^{56}$ Vote or no vote, the Chronicle concluded that 'this last position [Spain] was agreed on, and Benedictines are preferred'. The remaining item, that Salvado's body should be brought back to a tomb in the church, was simply referred to the new superior to sort out. In Europe, negotiating that return at the same time as he sought women for the mission, Abbot Torres's decision to invite the Teresians gave priority to the women's Spanish identity and formation as missionaries over any familiarity with the Benedictine structures or way of life.

The Teresians fell between categories. Ethnicity united them with the monks but divided them from the norms of both the English and Irish colonists and of Aboriginal Australians. In his visitation to the convent in 1907 Torres noted the sisters were using more than a whole jar of coffee every day at breakfast; he thought it important enough to record, although he did not comment further on the custom or its economy. ${ }^{57}$ He did indicate more clearly that daily classes in arithmetic and Castilian or Spanish grammar were a problem, because 'they don't study English, nor does the superior recommend it'. ${ }^{58}$

Language was an early and enduring barrier. That the Teresian sisters did not share the language of the girls and had no capacity to teach in it emerged as a major issue, alongside the sheer distance between Spain and Australia that made the communication of the abbot's expectations, and the response and oversight of the Barcelona superiors, so difficult. Torres had clearly expected that English-speaking members would be sent from the beginning. When only Consuelo of the original seven had any grounding in English, the mission had invested in increasing her capacity,

54 Chronicle, 6 October 1902. On the foundation of the Sisters of the Good Samaritan, see Margaret Walsh, The Good Sams: Sisters of the Good Samaritan 1857-1969 (Mulgrave, Vic.: John Garrett, 2001).

55 Chronicle, 6 October 1902.

56 Chronicle, 6 October 1902.

57 Visitation, 3.

58 Visitation, 5, 8. 
perhaps through lessons with the former schoolmistress or another local, 'so as to have her made ready' to head the integrated school. ${ }^{59}$ But then, as we have seen, the abbot was confronted with Consuelo's withdrawal in 1907 and her subsequent transfer to a Teresian school in Valencia.

Without Consuelo to bridge the language barrier between the Teresians and their charges, the school was in dire straits. The abbot had written ahead from Spain to reassure the community that among the four new Teresians 'there is one who can speak English'. ${ }^{60}$ 'Thank goodness for that at least', the Chronicle had remarked. ${ }^{61}$ But this was Sister Crisanta who in December 1907, after less than four months in Western Australia, had so mismanaged her office as local superior that she was on her way to Spain again. With a second superior returning in crisis, the Teresian leadership in Barcelona asked the abbot to do them the favour of applying to Rome to close the Teresian house at New Norcia and to 'take all the necessary steps to provide substitutes there for our community'. ${ }^{62}$ Teresa Blanche's letter was full of regret and defeat. She acknowledged 'only God can measure our pain on seeing so many efforts brought to nothing' ${ }^{63}$ and hoped 'the divine wisdom may draw from so much grief some small atom of glory'. ${ }^{64}$ Nevertheless, she alerted Torres that some of the sisters found 'the present conditions [at New Norcia] foreign to their vocations', ${ }^{65}$ and furthermore implied they would take a lawsuit against the abbot to Rome if he did not petition Rome to close the house. ${ }^{66}$

Abbot Torres remained focused on the school and his hope that the Spanish sisters might teach in English. In December 1907 he was not ready to give up on the Teresian community at New Norcia or the possibilities for St Gertrude's. ${ }^{67}$ Implacably, Torres replied to the superior in Barcelona that she could seek permission from Rome herself for the closure. He expected they would approach the authorities (and later claimed to have been 'waiting for the fulfilment of the threat ${ }^{68}$ ) but felt himself that patience might lead to improvement. He would not release the sisters from their commitment to New Norcia. 'No', the abbot wrote back in January 1908,

59 Torres to Pla, 3 May 1908, Visitation, 45.

60 Chronicle, 19 July 1907. On Crisanta as the English speaker, Torres to Saturnina Jassa, 3 May 1908.

61 Chronicle, 19 July 1907.

62 Teresa Blanche to Fulgentius Torres, 18 December 1907, Visitation, 38.

63 Visitation, 38.

64 Visitation, 38.

65 Visitation, 38.

66 Henry Altimira to Teresa Pla, 8 June 1908, points out this implication, Visitation, 48.

67 Visitation, 48.

68 Torres to Jassa, undated letter but by internal evidence 3 May 1908, Visitation, 43. 
'Wait and see if some sister or sisters reach the stage of being able to teach the white girls. ${ }^{69}$ In the meantime, he persuaded the Sisters of St Joseph who were already running primary schools in his far-flung diocese to send teachers to New Norcia for the new school year. On 8 January 1908 Sister La Merci, assistant to Mother Mary MacKillop, gave him the support he was looking for when she telegraphed from Sydney that the congregation would send teachers 'at least for the next term'.$^{70}$ Clearly aware of the tensions growing in the town, she also indicated that they were open to taking over the 'native girls' if, as everyone judged likely, the Teresian sisters did not continue. ${ }^{71}$

In Barcelona, however, the changes in the Teresian leadership that saw the election of the experienced missionary Saturnina Jassa meant there was new energy for the Australian house. Early in 1908 Mother Teresa $\mathrm{Pla}$, drawing on her firsthand knowledge of New Norcia gathered in the four months she spent there with the foundation community, wrote that they would send someone who not only spoke English but who also had qualities valued highly as part of the Spanish national character. She proposed someone 'competent, faithful, zealous for good works' who had taught English for some years. Teresa Pla also offered to come herself to 'settle things down'. ${ }^{72}$

The offer was no longer welcome. Only weeks before, Torres had been hoping for this, 'to gain time and see if the Superior General of the Teresians was taking better counsel'. ${ }^{73}$ But now, in March 1908, with Torres heading to the Kimberley on behalf of the new mission, Henry Altimira replied to Barcelona that 'the English religious', the Josephites, were in place, and the monastery was no longer resisting the withdrawal of the Teresians. Recent 'events' had cast doubt over any Teresian future at New Norcia:

In view of what has happened because of the three English religious having been put in charge of the college of the white girls duly authorised for it ... I beg to notify you that if you are still determined to withdraw ... the abbot will not place the least difficulty in your way. ${ }^{74}$

69 Torres to Blanche, 29 January 1908, Visitation, 39.

70 Chronicle, 8 January 1908.

71 Chronicle, 8 January 1908.

72 Pla to Torres, 28 April 1908, Visitation, 43.

73 Torres to Jassa, 3 May 1908, Visitation, 43.

74 Altimira to Blanche, 12 March 1908, Visitation, 39. 
He does not say explicitly what 'has happened' at New Norcia, but by then the message was clear: 'Don't bother to come. The Spanish sisters need to leave.' The English speakers who could run the school had priority over the Spanish sisters whose conflict with them was about more than language, as we shall see. What was at stake both in Barcelona and in the minds of the Teresians at New Norcia who were petitioning to stay was their missionary vocation.

\section{Missionary identity}

The arrival accounts and Maria Harispe's letter both gave a high priority to the work to evangelise and to be with the Aboriginal people. The same concern runs through the pages of the report on the canonical visitation. Some of the key difficulties in the community related to Sister Crisanta's lack of understanding as the new superior about how the missionary work was conducted and also perhaps about how much hard work, both domestic and on the farm, the Teresian sisters were doing alongside the $\mathrm{St}$ Joseph's girls. Photographs of a child practising the weaving that produced cinctures and other cords for the liturgy and a toddler sweeping with the twig broom that were taken to record the life at St Joseph's at the time give a much more tranquil picture than the account the established sisters gave the abbot. He recorded that, according to Sister Felipa Sanjuan, Crisanta struggled to assert her authority over the demands of mission work:

The superior has said that she can't work with due freedom, that she came to be superior and not a slave. ... The Sisters with due circumspection, drew her attention to the inconveniences which were caused by leaving the native girls alone in bed and letting them rise at their pleasure and without any supervision. The superior answered them: 'You are opposing what I am laying down.' Everyday with the exception of Monday when they are with the clothing, the girls who can't assist at class are without any supervision, with the weekly change of sisters in charge of the native girls, what one sister does the other undoes. The superior declared she would prefer to be in gaol rather than continue here in New Norcia. ${ }^{75}$ 
Other sisters echoed the concerns with the need to focus on the work in the school, to supervise the girls on walks and at work, and, a little surprisingly, on the freedom that the mission context gave the sisters in relation to the local superior because they could enlist the support of the abbot against her. A lay sister, Dolores Sol de Vila, put it to Torres that they were clashing with the superior over their access to the alternative authority of the monastery. Abbot Torres (or Father Altimira) recorded Dolores's summation of Crisanta's accusation in direct quotation marks: 'The ease we sisters have here in New Norcia of having recourse to the prelate, making clear what we judge necessary, and in this way they cannot suffocate us as happens in other parts. ${ }^{76}$

The full cooperation with the monastery that the Teresians were apparently claiming at New Norcia is especially interesting in the context of the wider literature on women's missionary work. Frequently, 'missionary' was an implicitly male term. ${ }^{77}$ The monks or the priests or the male ministers were the 'missionaries' and the women-whether accompanying nuns, or ministers' wives, or single women teachers, nurses and occasionally doctors-were framed as assistants, associates and helpmates. Salvado had distinguished the Sisters of Mercy from the 'missionaries' in his original party, ${ }^{78}$ and in the twentieth century New Norcia's Chronicle revealed a similar assumption, even as it paid tribute to Consuelo as an extraordinary missionary. Documenting the emotional impact of her sudden recall to Spain in a week when she was 'feeling it' and 'quite upset ... through her sorrow ${ }^{79}$ the diary keeper praised her for transcending her gender:

[Sr Consuelo] was perhaps never more distinguished than in what has been seen in these days, seeing that she had to overcome [the limitations of] her sex and condition, with her untiring perseverance in working without reserve for the good of the Aborigines, using her great talent in this. She has gained such great respect and love that the sorrow and tears at her departure were common to both the Aborigines and the European women. ${ }^{80}$

76 Dolores Sol de Vila, 28 October 1907, Visitation, 12.

77 Philip M. Kulp, ed., Women Missionaries and Cultural Change, Studies in Third World Societies 40 (Williamsburg, VA: Department of Anthropology, College of William and Mary, June 1987); Leslie A. Flemming, ed., Women's Work for Women: Missionaries and Social Change in Asia (Boulder, CO: Westview Press, 1989); Fiona Bowie, Deborah Kirkwood and Shirley Ardener, eds, Women and Missions: Past and Present; Anthropological and Historical Perceptions (Providence, RI: Berg, 1993).

78 Katharine Massam, 'Missionary Women and Holy Work: Benedictine Women in Western Australia', Journal of Australian Studies 39 (2015): 44.

79 Chronicle, 6 July 1907 and 16 July 1907.

80 Chronicle, 11 July 1907. 
Clearly appreciated by the monks as well as the Aborigines, and with a particular bond with the European women in town, Consuelo subsequently made choices that show how deeply she valued her missionary work. ${ }^{81}$ That she and other Teresians claimed their own vocation as missionaries and not simply 'helpmeets' challenged the assumptions of the day and disrupted their own community.

In writing to the cardinal in Rome with oversight of Catholic missionary work around the world in June 1908, Abbot Torres assumed that the women were 'helpers', not missionaries in their own right. In his letter supporting the requests of Leonor Bargallo and Teresa Roca to be released from their commitment to the Teresians, Torres foreshadowed the informal group of Benedictine oblates that would take their place:

For the rest, Your Eminence, the Institute of Religious Oblates of our Holy Father St Benedict in these regions whose primary duty would be to help our Benedictine missions amongst the Aboriginals would I think contribute to the greatest good and be an ornament of the holy Roman church. It would moreover, turn into the best help of our missionaries who only at great risk of their spiritual life can take care of young women and native girls in teaching them sacred doctrine..$^{82}$

His concern with the moral threat that would be overcome by having women to evangelise women echoed the original call to the Teresians in 1904. It related directly to the third dimension of identity that is entwined in the details of the visitation, that of gender or of the Teresians as sisters, not monks.

\section{Identity as sisters-not-monks}

The record of the visitation is overwhelmingly concerned with tensions that arise from understandings of gender and the appropriate role of women in the church. The impetus for the visit came in the first place (it seems) from complaints by the Teresians to Torres that the local superior (both Crisanta Lopez and her predecessor Montserrat Fito) was interfering with their consciences, asking individuals why they had not received communion, and refusing to call the extraordinary confessor

81 See Chapter 3.

82 Torres to unnamed cardinal, 5 June 1908, Visitation, 80. 
when they requested him. They did request him often-so much so that the depositions all agree almost in the precise wording that Crisanta Lopez used to tell her community to stop requesting the extraordinary confessor. She claimed that the extraordinary confessor was becoming the ordinary one and the superiors (probably in Barcelona, but perhaps of the monastery) had told the local superior not to go along with this. Such a refusal is in breach of canon law. As a result, Torres removed Crisanta Lopez from office.

Exactly what was going on in the repeated requests for the extraordinary confessor is open to interpretation. Perhaps the Teresians were scrupulous, or the ordinary confessor was hopeless, or the community simply preferred Planas and Altimira (the senior monks who were the extraordinary confessors) to Fr Mateu (the resident diocesan priest appointed as ordinary confessor), or perhaps they were playing the local superiors against the monastery. Or perhaps, and this is what Abbot Torres saw, the superior was usurping priestly authority and restricting the women's access to the sacramental life of the church.

There was more than just the restriction on access to confession to support Torres in this view. Crisanta Lopez had also prevented visits to the Blessed Sacrament in the church, telling the sisters instead to make the daily devotional act required by their directory in the convent chapel, where the Sacrament was not reserved. There were also practices that looked like the ritual exercise of authority, and these, Torres discovered in some alarm, were common to most Teresian houses. As the sisters remembered, tension between Montserrat Fito and Consuelo Batiz had included Consuelo's objection to the practice. Each day the sisters were required to kneel or prostrate themselves at the feet of the superior to seek absolution of their faults. Sometimes this followed a gathering of the house in chapter session where they accused each other of faults against the common life, but not always. When they left the convent building, they were also expected to kneel and ask the superior's permission. Torres was amazed, even though 'we ourselves have been eyewitnesses of this' ${ }^{83} \mathrm{He}$ summed up the difficulties to the cardinal as a usurpation of authority and as a mimicking of priesthood in particular:

The religious of the Society of St Teresa of Jesus labour under the greatest ignorance concerning the true subjection and obedience due to prelates. 
The Sisters come together regularly at night time before they sleep before the feet of the superior, so that kneeling they ask a blessing as from a priest. The superior ... imploring the help of God and St Teresa makes the sign of the cross over the one asking and presents her hand to be kissed ... having accused themselves of faults ... the superior at the pre-arranged time sits apart in a seat placed like a sacred minister there awaiting each member of the community. ${ }^{84}$

Shifting ground a little in his conclusion, the abbot lamented the harsh dictatorial demands that had replaced the love which is necessary to render light and sweet the yoke of Christ our Lord'. ${ }^{85}$ It is clear from the testimonies that the local superior was behaving erratically and was probably unsuited to the role, but the crisis came to a head because she appeared to lack the Christ-like and womanly quality of gentleness, on the one hand, while clutching after priestly power of decision making and care of souls, on the other.

Governance and the sisters' independence from the local bishop were also at issue. Like Mary MacKillop's Sisters of St Joseph in the 1870s, the Teresians had drafted constitutions that enshrined obedience to Rome through their own superiors, rather than a structure of distinct houses answerable to a local bishop. The central structure was part of 'the spirit of the Company'. ${ }^{86}$ It was identified with the founders, including Saturnina Jassa and Teresa Pla, who were both involved in decisions about the mission to Australia. ${ }^{87}$ But in July 1903 Rome rejected these first constitutions and approved a revised version that emphasised the authority of the local bishops. The Teresians welcomed the changes as a 'new grace' that affirmed the work of the congregation overall, but exactly how the revisions would affect local decision making was left to evolve. In 1905 the leadership issued a 'Directory' that included customs previously revoked by the approved constitutions, including the in-house practices of accusation and confession. Not surprisingly, different sisters came to different conclusions about the relative authority of the two documents. Torres found he was the first bishop to conduct a visitation of any house so far as the sisters at New Norcia knew. One sister believed that in certain customs of the house not even the Pope could interfere', ${ }^{88}$ while another

84 Visitation, 64

85 Visitation, 64.

86 Fernandez Pombo, Saturnina Jassá, 117, 126, citing La Compañia de Santa Teresa de Jesús 1876-

1932 (Barcelona: Ediciones STJ, 1969), 351.

87 Fernandez Pombo, Saturnina Jassá, 126.

88 Reported of Sr Montserrat, 30 October 1907, Visitation, 70. 
held that 'if the superior general did not order it she would not do it, even if twenty abbots or bishops ordered it' ${ }^{89}$ Abbot Torres was also bishop of the extensive network of parishes within the abbey nullius of New Norcia. A small scrap of paper in the monastery's copy of the approved Teresian constitutions, placed between the pages sometime before 1910 gave quick access to precisely those sections on local governance. ${ }^{90}$ It is not there by accident. The findings of the visitation and the letters Torres wrote to superior general Saturnina Jassà and to the cardinal heading the Congregation of the Affairs of Religious in 1907 and 1908 crackle with indignation and astonishment that the Teresian superiors would assume so much autonomy. ${ }^{91}$

While the bishop's difficulties with the structures and with the particular superior in charge were significant, they did not in themselves trigger the loss of confidence in the community that overtook Torres in February 1908. One particular incident at the start of the school year effectively sealed the fate of the community. Recorded only obliquely, the fragments nevertheless show that tensions about race fanned other smouldering issues into an open blaze.

\section{Race, and identity as not-White}

While the correspondence between the Spanish superiors traced concerns about language and women's spiritual authority, the Chronicle recorded that the Aboriginal girls were also apprehensive. With Torres and the Teresians, they had seen the tension erupt one night just after Christmas 1906, when a group of 32 Aboriginal men had raided St Joseph's and St Mary's, breaking windows, fences and flowerpots. Historians have read the incident as an effort by fathers to free their children after changes in New Norcia's administration made the institutions a target. The press in Perth had already noted the shift from the outward-looking mission of Salvado's era towards a more aloof institution under the new abbot. ${ }^{92}$ Aboriginal voices implicate Torres in changes that were insensitive and

89 Reported of Sr Luz, 29 October 1907, Visitation, 69.

90 Constituciones de la Compañia de Santa Teresa de Jesús (Barcelona: Tipografia Tersiana, Calle de los Angeles 22 y 24, 1903).

91 Visitation, 26-32, 33, 39, 60.

92 Lady Visitor, 'New Norcia Mission', Western Mail, 18 January 1902, 11; Massam, 'Cloistering the Mission', 16-18; Anna Haebich, Dancing in Shadows: Histories of Nyungar Performance (Crawley, WA: UWA Publishing, 2018), 163-67. 
cruel. From Eliza Willaway's remark to one visitor that 'he [Abbot Torres] noo [sic] understand yet' to letters of complaint to the government from Felix Jackimarra and George Shaw, two of the leaders of the Christmas raid, protesting that New Norcia was no longer a home for Aboriginal people, tension was rising. ${ }^{93}$ Following the damage to St Joseph's, Shaw, Lucas Moody and Emmanuel Jackimarra were arrested and jailed for three months. The monastery distanced itself from the men and referred their families to the Chief Protector of Aborigines for support. The Chronicle noted they were not mission families but 'from Catabody', somehow suddenly ignorant of ties that went back to Salvado in the 1860s. ${ }^{94}$ Approaching the first anniversary of that raid, the Aboriginal residents of St Joseph's saw the changes to their institution in racial terms. As firmly as any official of the White Australia policy, they drew a distinction between the Teresians from southern Europe and the Irish-Australian Josephites.

By December 1907 Abbot Torres was resisting the withdrawal of the Teresians, on the one hand, while also arranging for English-speaking teachers to open the school to 'white girls' in the new year. Three Sisters of St Joseph arrived a month later and commenced classes on Thursday 13 February 1908. The beautiful if sparsely furnished building of St Gertrude's had more than enough space for the two pupils, one aged about 11 and the other aged 18, who started school that week.

On the following Monday, 17 February 1908, a washing day, Abbot Torres was called away from a meeting to deal with a dispute. Only a serious argument would have warranted such urgent and personal attention. Sister Leonor Bargallo and Sister Maria Vilar had come to the monastery parlour to complain to the abbot. The issue was the washing of the white girls, students of the College. ${ }^{95}$ Maria Vilar spoke strongly and asserted three times that she had the support of the whole community: 'so say all of us', noted the Chronicle archly. ${ }^{96}$ That the matter was grave and gave the abbot 'great displeasure' was underlined in the Chronicle's hope for

93 Haebich, Dancing in Shadows, 168-69. Eliza Willaway reported by the 'Lady Visitor', Western Mail, 18 January 1902, 11; 'Treatment of Natives. New Norcia. Complaints re George Shaw and Felix Jackimarra', State Records Office of Western Australia (SROWA) S1644 cons652 1911/0473.

94 'New Norcia: Case against George Shaw and Others', SROWA S3054 cons968 1907/0505; 'Police, New Norcia Re: Arrests', SROWA S3005 cons255 1907/0108; Chronicle, 1, 11, 12 January 1907. See also Anna Haebich, For Their Own Good: Aborigines and Government in the South West of Western Australia 1900-1940 (Nedlands, WA: University of Western Australia Press for the Charles and Joy Staples South West Region Publications Fund, 1992), 17-18.

95 Chronicle, 17 February 1908.

96 Chronicle, 18 March 1908. 
'God [to] have mercy on them!'97 The abbot saw it as trouble 'from those from whom he least expects it ${ }^{98}$ — those Teresian sisters who had been at New Norcia since 1904. It was at this point that Torres dropped any idea that the Teresian community might remain at the mission. ${ }^{99}$

We do not know exactly what happened, or did not happen, in the laundry. Through the following week, the older Aboriginal girls (who would have been working in the laundry) were also making their own judgements. By the next Sunday at least six, possibly more, had left St Joseph's. Recording the departures, the Chronicle was succinct and pithily named the common cause that united the Teresians and the Aborigines as 'race':

Today another girl who is already of age left the Teresian Sisters, and four others went with her. How much these natives can not endure the presence of the whites, and our Teresians do not suffer less for the same reason! ${ }^{100}$

Clearly, both the Chronicle and the Aboriginal girls as reported by the diarist assumed that the Teresians were not white, or at least not in the same way as the Australian Josephites and their pupils were white. Even as the Chronicle seemed concerned to show the calm of that same Sunday following the dispute and recorded that everyone at St Gertrude's was at Mass and then Vespers together, there was also the subtle divide in the congregation of 'white girls and the Josephite Sisters ... equally the native girls with the Teresian Sisters' ${ }^{101}$ That division played into the dynamics about who would take on the domestic work of the college and triggered the Teresians' explosion about the washing. They had been prepared to wash for the monks and work with the Aboriginal girls to do this, but they refused the new expectation that they would wash for other women and 'white girls'.

It looked to the monastery as though the Teresians were 'immoral'. ${ }^{102}$ This was a strong judgement and the Chronicle's conviction that the offence was 'against the abbot ${ }^{103}$ probably means they were seen as having broken 
their vows of obedience. In a letter to Saturnina Jassa begun on 3 May 1908, Abbot Torres was more explicit about the fact of the problem but gave no details:

Meantime the Sisters here began to suffer from various ideas and especially with the presence of other religious and so it was that in a paroxysm of pique they did what afterwards they have regretted and to no purpose. ${ }^{104}$

Torres underplayed the cause as a skirmish between the women, yet for the monks there was no coming back from it. The sisters sought a compromise. Sister Felipa consulted Father Henry about a way to 'undo what they had done', ${ }^{105}$ but he could only advise her to ask for tickets to Spain. ${ }^{106}$ It became clear that Sister Maria Vilar had acted on her own initiative on 17 February and that, far from unanimously supporting her, four of the community knew nothing about it. Leonor wrote to the abbot to apologise for her part in the conflict. Maria Vilar along with the others deeply regretted 'the displeasure' and the stand-off that resulted. As they began to understand that their whole future at New Norcia was in jeopardy, the keeper of the monks' diary noted 'there are those who are weeping' about 'the blind alley' they had gone down. ${ }^{107}$

Sorrow was not a lever for change. The Chronicle argued it was only God who would console the sisters, not the monks, 'because for us after what happened that is morally impossible'. ${ }^{108}$ Perhaps resolution was impossible because, while the Teresians were sorrowful about the outcome, they were not in fact repenting of their refusal to do the washing. On 4 April 1908 Felipa and two others sought an interview with Torres and offered a crucial clarification. The Chronicle records 'they said to him, "that they did not want to do the washing of the white girls, as they were not their servants and had nothing to do with them"'. ${ }^{109}$

The two groups were living out a policy of separation in any case. At the same time as the abbot's secretary was encouraging the Teresians to withdraw from New Norcia, the word came from the monastery for the Aboriginal girls to move into the new college of St Gertrude's,

104 Torres to Jassa, undated letter c. October 1908, Visitation, 43.

105 Chronicle, 29 February 1908.

106 Chronicle, 29 February 1908.

107 Chronicle, 18 March 1908.

108 Chronicle, 18 March 1908.

109 Chronicle, 4 April 1908. 
'sleeping on the top floor'. ${ }^{110}$ The move was not about integration, as they continued to 'work, eat and study in the old [St Joseph's]'. ${ }^{111}$ When one of the Teresian sisters sought 'permission to take the native girls to the room [downstairs] on the left of the College Chapel for recreation' she was refused. The abbot 'did not judge it fitting. ${ }^{112}$ The Notebooks of the Benedictine Missionary Sisters comment that Sr Maria Harispe and the smallest children spent two years in this 'dance of comings and goings', going to bed early and rising early to avoid giving trouble and 'all this because of the discrimination between blacks and whites'. ${ }^{113}$ The southern tower still bore the Teresian crest in marble, and the recently installed foundation stone at the front door still announced the intention to bring Christian teaching to puellis indigenis but neither the Aboriginal girls nor their Teresian teachers could walk past it. Abbot Torres began planning to refurbish the old St Joseph's cottage as a second convent and school.

When St Joseph's was renovated and updated over the two years leading up to August 1910, a preliminary makeover concerned race. In August 1908 the Chronicle noted one of the community's artists, Brother Salvador, was restoring the image of the Blessed Virgin Mary that had been at St Joseph's 'for years. ${ }^{114}$ This was a devotional image that hung in the dormitory in which Mary 'appeared to be a person of mixed blood'. ${ }^{115}$ Perhaps the painting was New Norcia's copy of Mary as 'Our Lady of Guadalupe', a title made famous through Spanish missions to the Americas. We know Abbot Salvado was given such an image, among others, and that it has been restored. ${ }^{116}$ Whether or not Brother Salvador was working on the Guadalupe Madonna, the instructions he was given betray much about New Norciass ideals of holiness, feminine beauty and race. Brother Salvador's task was to correct the impression of Mary's mixed descent. He did this successfully in the opinion of the Chronicle, leaving it 'as new, as it has not been known before'. ${ }^{117}$ Intriguingly, at the same time, the dark, carved features in Juan Casellas's image of Our Lady of Montserrat, icon of Spanish and Catalan identity, were an undisputed treasure of the monks' chapel. It was not skin colour as such but the Madonna's mixed

110 Chronicle, 12 March 1908, on the letter to Barcelona, 14 March 1908.

111 Chronicle, 12 March 1908, noting a move to the new college 'last Saturday', 7 March.

112 Chronicle, 23 March 1908.

113 Notebooks, Madrid, 5.

114 Chronicle, 6 August 1908.

115 Chronicle, 6 August 1908.

116 Chronicle, 6 August 1908; Dom Christopher Power, OSB, email correspondence, 28 April 2014.

117 Chronicle, 6 August 1908. 
heritage that triggered the intervention at St Joseph's. The Chronicle approved of the restoration, and the image was blessed in a ceremony on the feast of the Assumption a few weeks later. ${ }^{118}$ We can only imagine the impact on the Aboriginal girls and the sisters; 'half-caste' could no longer stand as 'holy'.

At the practical level of building work, the Chronicle recorded steady progress. The renovations included a verandah, newly concreted and painted; new bathrooms; a better stove, moved from the monks' novitiate; and dormitory buildings freshly plastered, painted and with galvanised iron roofing instead of thatch. Large water tanks and a new laundry were also noted as 'giving very good results'. ${ }^{119}$ When it was complete the monks recorded the praise it attracted from the Josephites at St Gertrude's. They thought it looked like a 'true College for Girls, such as you might find in various important towns, not excluding some colleges in Perth'. ${ }^{120}$ To emphasise the good comparison the diary-keeper inserted 'white' above the reference to girls' colleges elsewhere, clarifying both the high praise and the prevailing assumptions about real education. ${ }^{121}$ Certainly the dedicated facilities at St Joseph's were superior to the makeshift and cramped schools in many Catholic parishes in Perth. The new buildings also blended with the cottages that housed the Aboriginal families and the low rise of the monastery itself some distance away. But everyone could see they did not match the neighbouring towers of St Gertrude's and the generous classrooms available there; in fact, there was no mention of classrooms in the St Joseph's renovation at all. For the Aboriginal people there was also another issue. The most striking new feature was a high dividing wall.

Enclosure was a powerful theme in monastic life, especially for women, but this wall organised space along racial rather than religious lines. There had been no move towards a formal cloister for the Spanish sisters before 1910, and this move sequestered them with, not apart from, the Aboriginal girls. The monastery's Chronicle gives the only accounts we have of reaction to this change, and the focus is on the horrified response of the Aborigines. As well as dividing the white and native colleges, the Chronicle read reactions against the wall as a sign of lack of civilisation.

118 Chronicle, 15 August 1908.

119 Chronicle, 16 October 1908. Also 26 September 1908, 17 October 1908, 25 January 1910, 22 April 1910, 10 May 1910, 28 May 1910, 8 June 1910, 23 June 1910, 8 August 1910.

120 Chronicle, 17 July 1910.

121 Chronicle, 17 July 1910. 
The Aborigines' nickname for the new enclosure, 'Golden Gaol', suggested a wry appreciation of the quality of the work but was also a clear rejection of the project. Perhaps they intended to echo the name given to the Salvation Army's house in Perth, the 'Golden Gate', where young women also worked in a laundry. ${ }^{122}$ On the day it was completed in February 1910, the Chronicle recorded in some bewilderment:

Finished the brick enclosure near the college of the native girls, and God knows who it will be useful for because the coloured people both within and without abhor nothing so much as the 'Golden Gaol' as one of the girls who escaped from it called it recently. The place is spacious and beautiful and can only be hated by bush people. ${ }^{123}$

The escape the Chronicle referred to may have been as simple as the dignified exit described a few weeks earlier when Katie Yapo, one of the older girls, nearly 15 , simply left quietly after supper 'having served the rest of her companions'. ${ }^{124}$ It was a week when the sisters themselves were in turmoil about their own departure for Spain, but, touching on the realities of institutional life, the Chronicle discounted other likely reasons for Katie's decision: 'nothing about repression on the part of the sisters nor about a quarrel with her companions'; she had told her friends she was leaving 'because she didn't want to be in the college any longer'. ${ }^{125}$ Whether trauma or simple choice lay behind her move, that she had wanted to be there but now had changed her mind, is significant, as it is significant that the 'Golden Gaol' had only recently been nicknamed a prison. What had changed, the Chronicle said clearly, was the wall:

The true reason [for her leaving] seems to be on seeing how advanced they were with the walled enclosure of the college which stinks for them as it does for all the natives in the village. They all regard it as a prison. ${ }^{126}$

122 Penelope Hetherington, Paupers, Poor Relief and Poor Houses in Western Australia 1829-1910 (Crawley, WA: University of Western Australia Publishing, 2009), 132.

123 Chronicle, 18 February 1910.

124 Chronicle, 30 January 1910. See Catalina Yapo in Aborigines of New Norcia 1845-1914, ed. Neville Green and Lois Tilbrook (Crawley, WA: University of Western Australia Press, 1989), 170.

125 Chronicle, 30 January 1910.

126 Chronicle, 30 January 1910. 
Declaring itself against their protest by condemning the illicit trysts that freedom would make possible, the Chronicle inadvertently confirmed the high value that the young Aboriginal women placed on 'liberty', against the new situation the sisters found themselves supporting. 'Praised be God', the writer observed ironically, 'In this way [by leaving] they will have an opportunity to give themselves to X. ... They are not worried about the hunger they will have to endure for the sake of this liberty [sic]'. ${ }^{127}$ The walled enclosure defined a racial and gendered zone. The assumption that protection and even privilege lay inside it reflected a shift in the missionary approach at New Norcia. Significantly, the Aboriginal girls shared the enclosure with the Spanish sisters.

The evolution of two distinct schools began as a pragmatic response to the situation where the Spanish speakers could not teach in English but became firm mission policy in response to conflict or the fear of conflict between the two groups. The Sisters of St Joseph were open to having Aboriginal children in their school, but the girls themselves were voting with their feet against integration. Some were willing to cross the divide but risked unleashing controversy. For example, in 1908 one of the diocesan priests resident at New Norcia had made a unilateral decision to 'put the young native girl in the College with the white girls'. ${ }^{128}$ We do not know the name of either the student or the priest or what motivated the move, but the Chronicle recorded that Henry Altimira, missionary trained by Salvado, trusted confidant of the Teresians, efficient secretary to the abbot and, by this time, also the monastery's procurator, 'disapproved of his action and condemned it strongly'. ${ }^{129}$ Fr Altimira would have been well aware of the unrest and anxiety among the Aboriginal girls due to the new school. Probably he also had the power to have reversed the priest's decision.

127 Chronicle, 30 January 1910.

128 Chronicle, 12 June 1908.

129 Chronicle, 12 June 1908. 


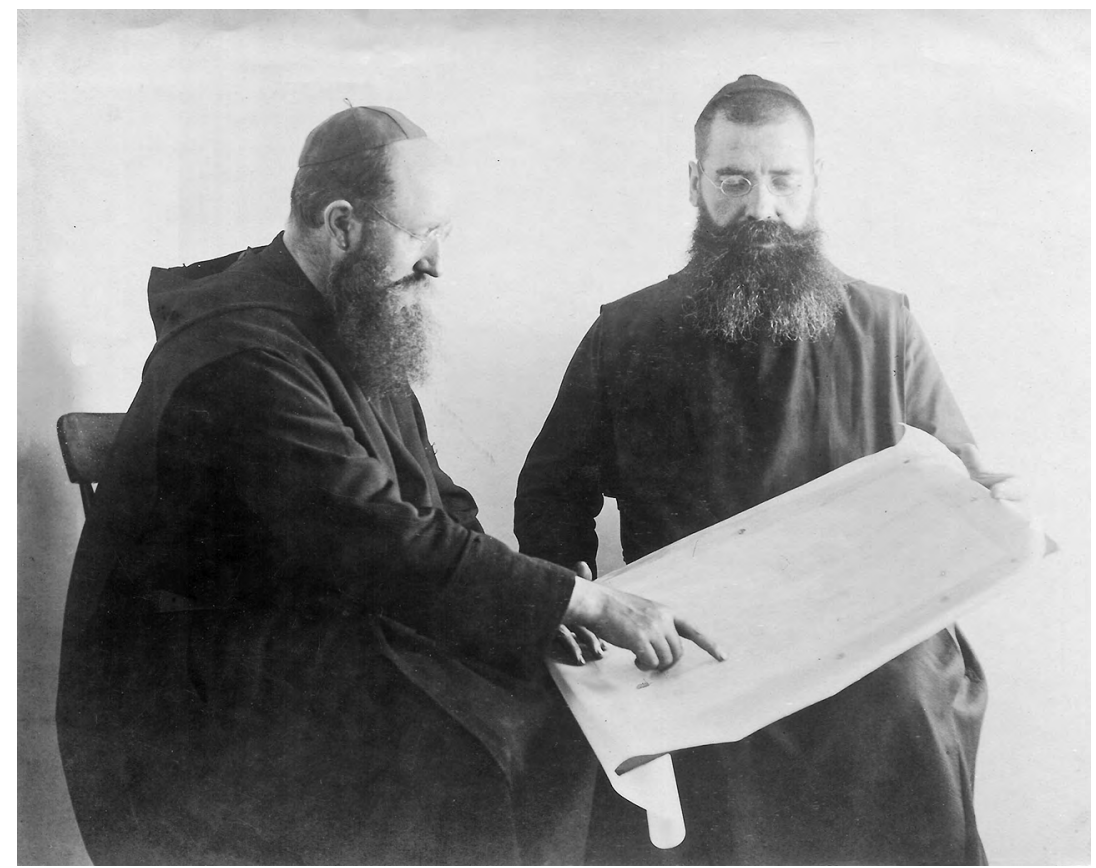

Figure 2.5: Fr Henry Altimira and Fr Planas with plans for the Drysdale River Mission.

Source: NNA 24821P.

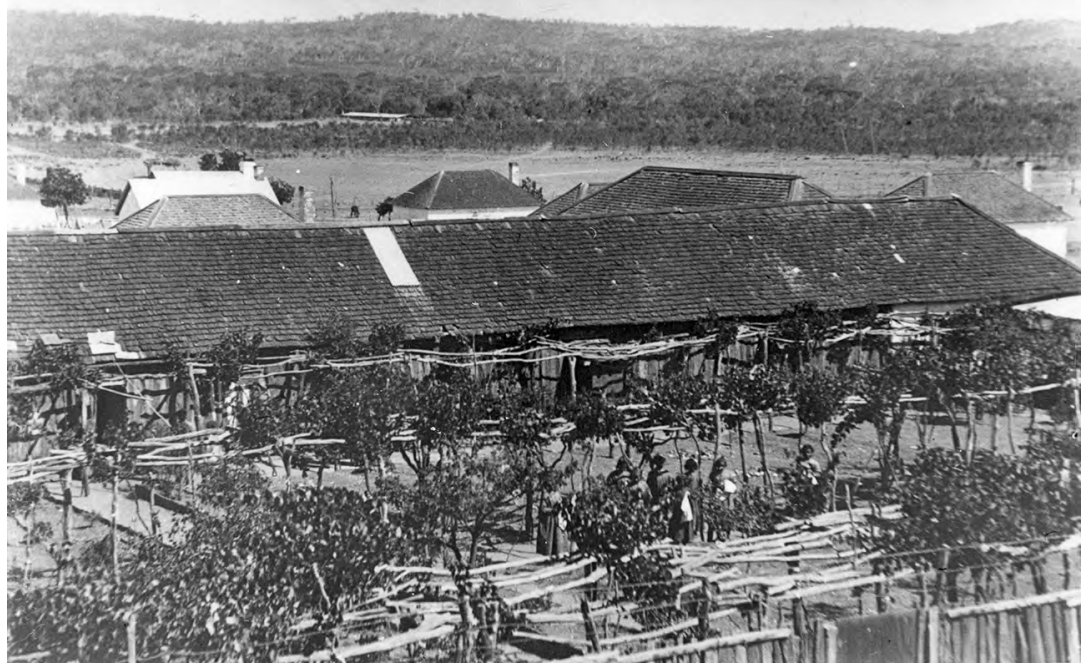

Figure 2.6: St Joseph's from the southern tower of St Gertrude's, c. 1907.

Source: NNA 74603P. 


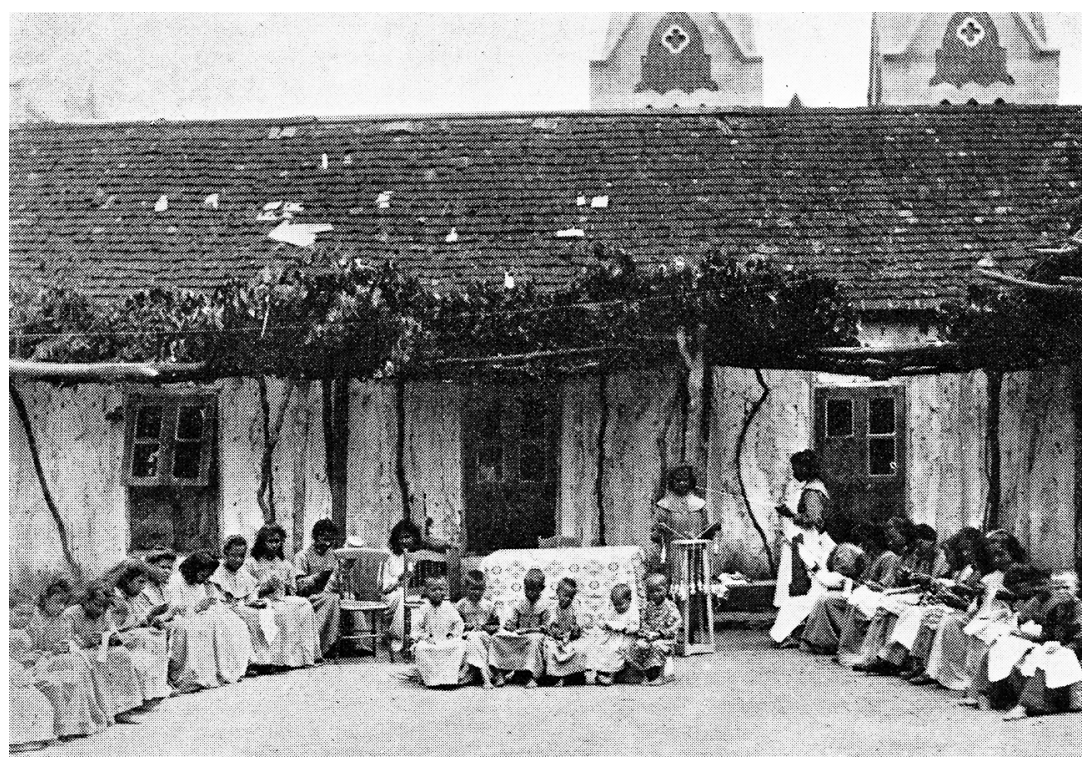

Figure 2.7: St Joseph's girls assembled to show skills in weaving and sewing, with the towers of St Gertrude's in the background.

Source: NNA 74904P.

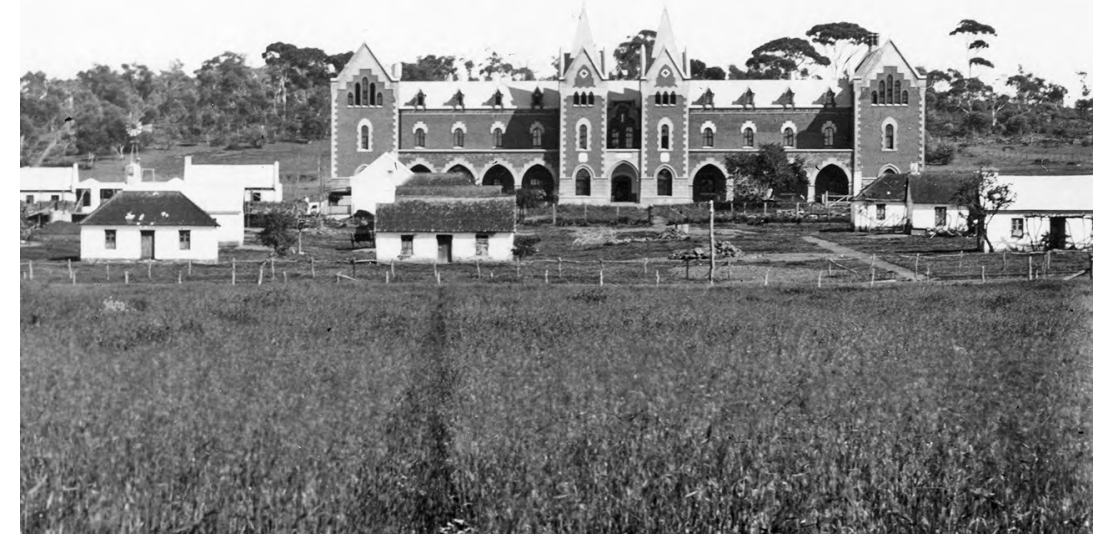

Figure 2.8: St Gertrude's College c. 1909, with the buildings of St Joseph's to the left and cottages in the foreground.

Source: NNA 74616P. 


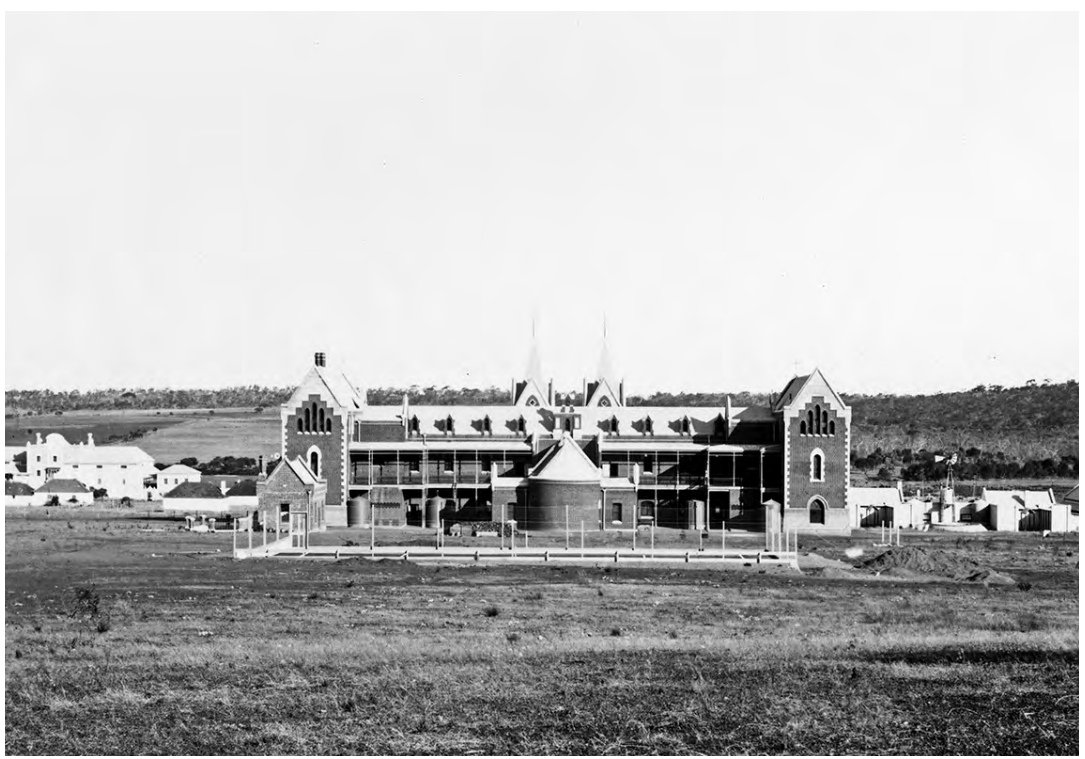

Figure 2.9: St Gertrude's and St Joseph's looking east c. 1908.

Source: NNA 74408P.

The Chronicle records an irate scene. ${ }^{130}$ The priest found the procurator talking with some young monks and an Aboriginal man. He confronted Altimira, 'attacked him', the Chronicle says, and told him he was going to kill him. The diary-keeper, 'one who heard', took the threat seriously. Not missing a beat, Altimira told him, effectively, to put it in writing. Diffusing the situation with good sense and wit, Altimira got the priest's 'indignant' promise to commit the complaint to paper. Two-and-a-half hours later, the long letter that was slipped under the procurator's door did not repeat the death threat. Instead, it explained 'in very different terms' why the priest had tried to make a place for the girl at St Gertrude's. We do not have the letter, or any further detail at all, but there is something poignant about the furious exchange falling back into ordered account and then silence. The changes at the girls' schools stirred deep emotion but had an unassailable momentum. 
The hope that St Gertrude's would be a school for Aboriginal girls to rival anything in Europe sat awkwardly in New Norcia's continuing history. The foundation stone's commitment to puellis indigenes came to be translated as education for 'Australian girls', ${ }^{131}$ and while some Aboriginal people remembered the new buildings had started out 'for the natives', they gave credit to Salvado, not Torres. ${ }^{132}$ Where Torres's original intention was acknowledged, the reasons given for the change were fuzzy. They included an initial lack of realism on Torres's part, as he had 'underestimated' the degradation of the Aboriginal people in the south, and implied the resistance of farming families to send their daughters to a mixed boarding school. Both of these ignored the decisions the Aboriginal girls themselves were making and discounted the situation the Teresian sisters faced as their involvement in the project dissolved. St Joseph's continued as a separate institution with a small, much less ambitious school. Overall, the focus on the institutions for children suggested a narrower vision, less sympathetic to engagement with Aboriginal people, and one that prompted rather than responded to the departure of many Aboriginal workers and their families from the town. Bernard Rooney and Anna Haebich argue that the second abbot's policies actively caused the 'Yued diaspora', driving Aboriginal families from New Norcia to fringe camps and other institutions, as the mission sold farmland to fund new buildings and expansion in the Kimberley. ${ }^{133}$ The opening of the new boarding colleges came to mark a 'new era' as the town focused on education, rather than on missionary work.

The Teresian sisters had come as missionaries to the Aboriginal people and, as Maria Harispe's letter shows, were looking for ways to live out that commitment 'for the mission' but not through domestic work in another congregation's school. Neither did the abbot's proposal that they should continue at New Norcia and be answerable to him make any sense to this group. If Maria Harispe, Leonor Bargallo and Teresa Roca saw their future continuing 'to assist the native girls', ${ }^{134}$ it would have to be, as Torres

131 For example, The Golden Career of St Gertrude's College, New Norcia 1958 (New Norcia: The Abbey Press, [1958]) (NNA).

132 Harold Willaway, cited in Haebich, For Their Own Good, $17 \mathrm{n} 34$.

133 Bernard Rooney, The Way of the Boorna-Waangki: A Tale of Cultural Endurance (Melbourne: Abbey Press, 2014), 111; Haebich, Dancing in Shadows, 163-64; Bob Reece, "Killing with Kindness": Daisy Bates and New Norcia', Aboriginal History 32 (2008): 137-38.

134 Chronicle, 25 February 1910. 
knew, a new commitment to the work of New Norcia in particular. Facing this reality, even the finances for their travel caused conflict. The Teresian community could not decide to stay without the support of the abbot, but neither could the abbot send them home without the approval of their councillors. When Barcelona refused the mission's request to pay for tickets, New Norcia responded with the news that the sisters would not travel until their pensions had built up to the amount needed for a thirdclass berth.

In the negotiations with the Barcelona leadership over payment for the sisters' fares, Torres and Altimira also found themselves dealing with women who, on the one hand, were willing to argue the toss about who funded the travel (Barcelona paid in the end) and, on the other, to call on the authority of their own spiritual heritage to assert their right to keep the house open. Mother Saturnina Jassa did not expect Abbot Torres to make a decision about the foundation for her; she was expecting to discern for herself what God intended in the debacle:

Who knows whether we needed to pass through this mighty tempest so that the daughters of the great Teresa who loved souls so much might be extended in those distant countries and contribute not a little to the Christianisation of peoples. ${ }^{135}$

In the end, however, she had to acknowledge that the sisters and the monks were not going to be able to agree. In convoluted Spanish that probably reflected the stress of the situation, she complained of the 'succession of misunderstandings', especially to do with the qualities suited to the work there:

I understand that a large part of the personnel ... was not suitable for the nature of a mission in which the principal role is played by the glory of God which has to be carried out to the end in those points mentioned through various manifestations of Christian charity. ${ }^{136}$

Then she gathered herself together and summed up what she thought New Norcia required: 'That is to say, knowing how to be all for all'. ${ }^{137}$ She went on to suggest ways in which she could even now make sisters available, who had enough English, and the right 'zeal for souls'. 
Abbot Torres did not accept Saturnina Jassa's offer. Neither was he able to accept the offer from Leonor Bargallo and Teresa Roca that they stay on. No dispensation from their vows arrived. They left New Norcia to sail for Spain in February 1910. ${ }^{138}$ Maria Harispe had taken new vows as a Benedictine oblate in July 1909, when her temporary profession with the Teresians expired. She continued to superintend the complex in the shadow of St Gertrude's for two years, with help from one of the Josephites as a teacher, until in 1912 a small community began to gather around the work at St Joseph's.

The tensions of the Teresian years did not disappear. The women continued to wrestle with ethnicity and racial difference, spirituality and expectations of women's work in the crucible of monastic and missionary commitment. In a sense, 'Benedictine Oblate Sisters', as they came to be known, took on Saturnina's challenge; they were willing to embrace 'being all for all'. 
This text is taken from A Bridge Between: Spanish Benedictine Missionary Women in Australia, by Katharine Massam, published 2020 by ANU Press, The Australian National University, Canberra, Australia. 